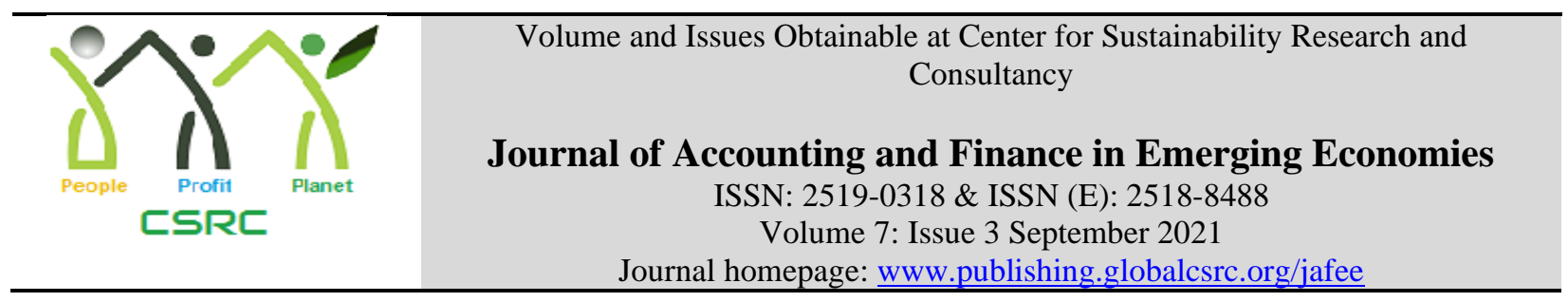

\title{
How Does the Accounting Conservatism Affect the Stock Price Crash Risk in Pakistan: The Complementary Role of Managerial and Institutional Ownership?
}

*Aon Waqas, Department of Commerce, University of Karachi, Karachi, Pakistan

Danish Ahmed Siddiqui, Karachi Business School, University of Karachi, Karachi, Pakistan

*Corresponding author's email: waqasaon@gmail.com

\section{ARTICLE DETAILS \\ History \\ Revised format: Aug 2021 \\ Available Online: Sep 2021}

\section{Keywords}

Accounting Conservatism, Stock Price Crash Risk, Managerial Ownership, Institutional Ownership. Agency Problem,

JEL Classification M10, M14, M20, M41, M42

\begin{abstract}
Purpose: The conservatism of accounting and robustness of accounting information disclosure may restrain the irrational behavior of investors and help to reduce the risk of stock price crashes. This study aims to explore this in the context of developing country Pakistan. More specifically, this study investigates the effect of accounting conservatism on stock price crash risk. We also examine the complementary role of managerial and institutional ownership in strengthening this effect.
\end{abstract}

Design/Methodology/Approach: This study conducts the panel data analysis of 155 nonfinancial firms listed in PSX from 2007 to 2019. This study calculates the $\mathrm{C}$-Score to measure accounting conservatism. This study measures the firm's stock price crash risk by calculating the DUVOL of weekly share prices.

Findings: This study finds that there is a significant negative effect of accounting conservatism on firms' stock price crash risk. This study also finds that managerial ownership enhances the stock price crash risk of the sample firms significantly as a moderator while there is no significant moderating influence of institutional ownership.

Implications/Originality/Value: The competent authorities of Pakistan should consider agency conflicts. They should direct the firms' management to share equal information in time regardless of whether the information is good or bad for stock prices.

(C) 2021, The authors, under a Creative Commons AttributionNoncommercial 4.0

Recommended citation: Waqas, A. and Siddiqui, D. A. (2021). How Does the Accounting Conservatism Affect the Stock Price Crash Risk in Pakistan: The Complementary Role of Managerial and Institutional Ownership? Journal of Accounting and Finance in Emerging Economies, 7 (3), 607-621. 


\section{Introduction}

Accounting conservatism is an indispensable attribute of financial reporting quality to improve the reliability of firms' financial statements (Mohammed et al., 2010). Financial statements are made by business enterprises to share earning information. Earning information communicates the financial performance of the companies. Earning information is one of the key concerns in financial disclosure (Alhayati, 2013). The earning information should be disclosed according to the principles of accounting. The accounting principle that primarily relates to ensuring disclosure quality of reported earning information is the conservatism principle of accounting (Ruch \& Taylor, 2015).

The accounting conservatism principle deals with economic uncertainties and circumstances to delay in anticipation of good information than bad information. The accounting conservatism principle affects the figures of financial statements because cost and loss are recognized better than revenue and profit (Hajawiyah et al., 2020).

Firms' management opportunistic behavior and agency conflicts between firms' shareholders and managers because of asymmetric information lead to making an inefficient investment by choosing that projects having negative worth rather than selecting that investment projects having positive net present value (Verdi, 2006). Furthermore, according to Wang et al., (2020) firms' management tries to hide the negative information because of agency conflicts and asymmetric information but when such information is shared then results in the firms' stock price crash.

Lafond \& Watts (2008) find that accounting conservatism minimizes the risk of the stock price crash with the help of disclosure quality of information. Kim \& Zhang, (2016) confirm that possibility of firms' stock price collapse risk is reduced with accounting conservatism. Accounting conservatism is applied to avoid the opportunistic behavior of the management to control the agency cost (Stein, 2003).

Accounting conservatism controls the agency cost and has benefits for corporate governance in several ways. First, conservatism limits the over-payments by management to parties with loss recognition in time rather than profit's recognition (Watts, 2003). Second, conservatism controls the manager's opportunistic behavior to invest in negative net present worth projects (Osama \& Penalva, 2009). Third, firms' management tries to escape from negative investment projects under accounting conservatism because it causes economic loss that can be timely anticipated (Watts, 2003). Fourth, conservatism-based disclosure of information predicts the sustainability of firms' future earnings, investors' behaviors and, minimizes the stock price crash risk (Wang et al., 2020).

The agency problem is more serious because of the centralized ownership structure in Pakistan. The agency problem can be resolved with the help of the transparency of information. The transparency of information is possible with the help of audit and disclosure quality. The audit and disclosure quality are possible when firms try to catch the interest of the shareholders by making an efficient investment. An efficient investment helps to ensure that investors have trust in managers' decisions and there is no conflict among them. The interest and trust of the shareholders lead to reduce stock price crash risk. The stock price crash risk is possible when the firms anticipate the Bad-News in time rather than anticipate the Good-News (Basu,1997).

Mitton, (2002); Lemons \& Lins (2003) summarize those crashes in stock prices of the firms because of a weak corporate governance system and ignorance of Bad-News are more if we compare with such firms that have a good corporate governance mechanism to anticipate the losses more quickly or in time as compared to their profits or Good-News. 
If Bad-News does not anticipate in time and withholds by the firms' managers for an extended time, then Bad-News is likely to be stockpiled within firms. However, when the accumulated Bad-News reaches a certain threshold and if releases at once that leads to the risk of stock prices collapse. This step is also considered as bad governance because of no use of the accounting principle of conservatism (Hutton et al., 2009; Jin \& Myers, 2006).

The prior research literature on developed economies has documented that overall good corporate governance mechanism with its attributes relate to accounting conservatism (Lafond \& Roychowdhury, 2008; Ahmed \& Duellman 2007; Beekes et al., 2004). However, the ownership structure in Pakistan is slightly different from the USA, UK, China, and other emerging global economies. The ownership structure is centralized in the hands of political shareholders. The government officials are shareholders with a majority in business firms. The legal system of Pakistan is weak, even no rule of law and, no enforcement of legal regulations that lead to an ineffective corporate governance system.

But this issue can be resolved by addressing the policy guidelines of IFRS that demands firms to disclose quality information regardless of whether the Bad-News or Good-News. IFRS motivates firms to good corporate governance attributes that lead to follow the conservatism principle of accounting (Latif et al., 2020).

Prior research studies have been conducted in such relevance but the context of developed economies with a limited scope and sample size like (Kim \& Zhang, 2016) conduct a research study to check the impact of conditional accounting conservatism on stock price crash risk by picking sample firms from the USA from 1962-2007. This study considers these two variables only by leaving a research gap for the future.

Similarly (Hunjra et al., 2020) try to fulfill the research gap by checking the impact of accounting conservatism and corporate governance on stock crash price only for the manufacturing sectors of Pakistan and India from 2010-2018 by considering 355 manufacturing firms as a sample for their research. They measure the corporate governance with limited attributes rather than considering the overall corporate governance index for cross-country measurement. This research has a gap to consider all sectors especially non-financial sectors of the Pakistan stock exchange.

The ownership structure of Pakistan has been centralized. Horse-trading is a priority. The firm's management has its benefits. The managers hide useful information from the investors. There are conflicts of interest between the managerial owners and institutional owners. Unfortunately, no such research study has been found in an Asian context that considers managerial ownership and institutional ownership as a moderating variable to measure the consequences of conservatism on stock price crash risk in developing economies like Pakistan by considering all non-financial sectors in one study.

Therefore, this study fulfills the above-mentioned research gap and is helpful for investors, stakeholders, management, and policymakers of non-financial sectors of South Asia, especially in Pakistan.

\section{Literature Review and Hypothesis Development}

\section{Research on Stock Price Crash Risk}

Kim et al. (2011) define the stock price risk by stating that "the negative deviation degree of weekly stock returns after stock market adjustments" and Xu et al. (2013) classify the stock price 
crash risk by using a dummy variable. Further, they define stock risk as "the difference of stock volatility between rising and fall of stock prices in the stock markets".

$\mathrm{Xu}$ et al. (2012) find in their research that there is a significant positive relationship among optimistic biases of stock analysts and stock price crash risk at present and in the future after adjustments made by listed firms according to stock markets adjustments because of conflict of interest of institutional investors for refinancing commission etc.

Yang et al. (2018) find that stock prices of firms have a certain degree of deviation that has a high level of goodwill in stock markets that enhances the stock price crash risk. Further, (Chen \& Zhou, 2016) state that high-quality auditing and many institutional investors play an effective role in the betterment of the corporate governance mechanism of the firm to improve the transparent disclosure of information about firms' cash-flows. Thus, by this stock price crash risk of the listed firms can be controlled and minimized.

\section{Research on Accounting Conservatism and Stock Price Crash Risk}

Lafond \& Watts, (2008) find that accounting conservatism can reduce the risk of stock price collapse by improving information transparency. Kim \& Zhang, (2016) confirm that accounting conservatism can reduce the company's future stock price plunging. Hu et al. (2014) confirm that accounting conservatism can promote the transfer of enterprise-specific information to external personnel and improve the quality of the information disclosure.

Wang \& Xie, (2013) analyses the interaction between accounting conservatism and the information environment. Wang, (2015) finds that accounting conservatism and the product market competition have a complementary relationship when exerting the effect of suppressing the stock price collapse risk.

Quan \& Xiao (2016) analyze and test the transmission path of "Corporate Responsibility Information Disclosure - Accounting Conservatism - Stock Price Crash Risk" in China's Capital Market. Based on this argument, many researchers have empirically proved that there exists a negative relationship between a firm's stock price crash risk and accounting conservatism.

The "asymmetric disclosure behavior" of the firm's manager causes that such a firm must face negative news and must accumulate bad information respectively. But when such information is disclosed thus the stock prices of such firm collapse faster than other. Firms try to anticipate the negative news more than the good news to control such collapse with the help of conservatism (Watts, 2003).

\section{H1: There is a significant negative effect of accounting conservatism on stock price crash risk.}

\section{Research on Accounting Conservatism, Stock Price Crash Risk, and Managerial Ownership}

Ding et al. (2007) report that the owners manage earnings in the upward direction. Young et al. (2008) empirically prove that ownership structure is negatively related to conservatism. Kung et al. (2010) examine listed companies in China and report that firms with concentrated owners deploy less conservatism in reporting accounting information. The reason is that the owners can solve conflicts of interest personally hence reduced conflict of interests means reduced agency conflict and hence decreased conservatism. 
Lafond \& Roychowdhury (2008) set forth the evidence of the existence of a negative association between conservatism and management ownership. Their argument is simple. They say that if the managerial interest is not aligned with that of shareholders, the demand for conservatism is increased.

Mohammed et al. (2017) argue that the greater the number of shares held by the managers in the firm, the lower is the demand for conservatism. The reason is simple. The managers are more informed about the resources as well as the position of the firm. They can use this information to gain personal benefits through the inefficient allocation of scarce resources available to the firms. Hence, they demand less conservatism.

Jin \& Myers (2006) state that managers try to hide the bad news when a firm's cash flows are less than the expectations of the firm's investors. But when the accumulated bad news crosses the tipping point and is released by the management then stock prices crash (An \& Zang, 2013).

Another viewpoint is that in the case of more managerial ownership the agency conflict is less thus there is no need of using conservatism. Based on this argument many researchers have empirically proved that there exists a negative relationship between managerial ownership and accounting conservatism that increases the firm's stock price crash risk.

H2: Managerial ownership moderates the effect of accounting conservatism on stock price crash risk.

\section{Research on Accounting Conservatism, Stock Price Crash Risk, and Institutional Ownership}

Kim \& Jung (2007) argue that if the ownership of the firm is not dispersed among outsiders, this reduces the quality of financial reporting which in turn has adverse effects on the firm's efficiency and performance. Lin et al. (2014) and later Mohammed et al. (2017) while addressing the role of ownership concerning the level of conservatism in listed firms, argue that the greater the number of shares held by the outsiders (i.e., by institutions, foreign investors, etc.), greater is the demand for quality in financial reporting.

Hutton et al. (2009) state that institutional owners are mostly within the management of the firm. They are controlling a major part of the useful information. A major portion of the firm's shares is held by them. They know bad news but when such accumulated bad news is released by them or accumulated bad news is come out in the stock market with different circumstances that lead towards the collapse of stock prices. Then investors monitor bad news hoarding by expecting that institutional ownership influences the stock prices negatively.

This demand compels the managers to go for conservative accounting estimates. Based on this argument many researchers have empirically proved that there exists a negative association between institutional ownership and accounting conservatism that enhances the firm's stock price crash risk.

H3: Institutional ownership moderates the effect of accounting conservatism on stock price crash risk. 


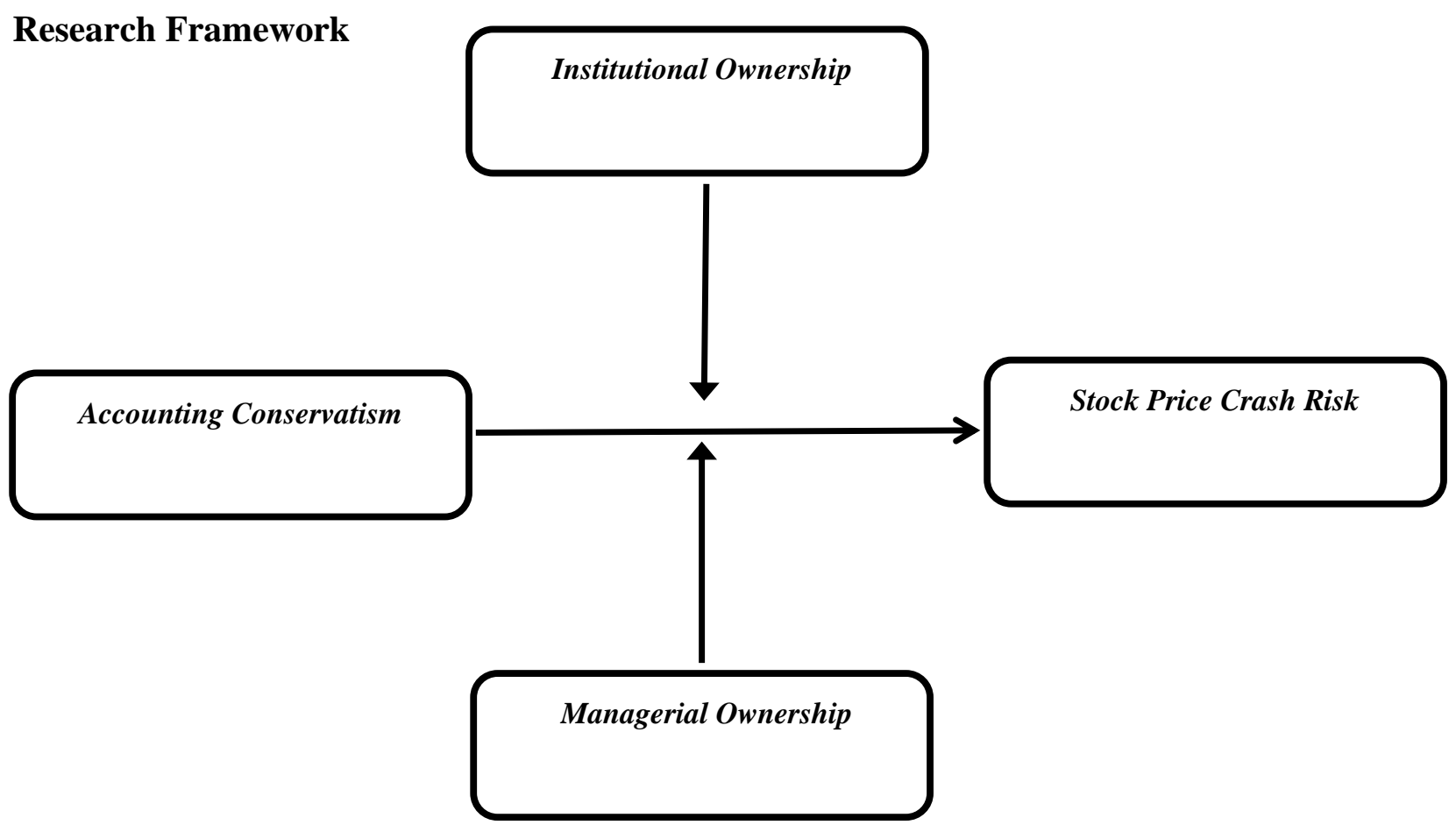

\section{Research Methodology}

\section{Sample Size and Data Collection}

The sample of this study consists of listed firms in the Pakistan Stock Exchange (PSX) from 2007 to 2019. Financial firms and insurance companies are excluded. This study considers only 155 non-financial firms. The reason is that to collect data only from the non-financial sector because there are significant structural and reporting differences. Secondary data is extracted from PSX, financial reports of the sample firms, and online sources for the estimation.

\section{Estimation of Accounting Conservatism}

For the estimation of accounting conservatism C-Score model by expending the Basu model (Basu, 1997) is applied in this study. Researchers (Zheng \& Liu, 2014) believe that for the estimation of good-news G-Score while for the estimation of bad-news C-Score can be applied (Khan \& Watts, 2009) with the help of the firm's size (SIZE), market to book ratio (MTB), and debt to equity ratio (LEV).

$\mathbf{G}=\mu_{\mathbf{0}}+\mu_{1} \mathbf{S I Z E}_{\text {it }}+\mu_{2} \mathbf{M T B}_{\text {it }}+\mu_{3} \mathbf{L E V}_{\text {it }}$

$\mathrm{C}=\lambda_{0}+\lambda_{1}$ SIZE $_{\text {it }}+\lambda_{2}$ MTB $_{\text {it }}+\lambda_{3}$ LEV $_{\text {it }}$

SIZE is measured by taking the natural logarithm of the total assets. MTB is measured by dividing the market value of the share by to book value of the share. LEV is measured by dividing debt by equity of the firm $i$ and year $t$.

$\frac{E_{P S}}{P_{i t}-1}=\beta_{0}+\beta_{1} D_{i t}+\beta_{2} R_{i t}+\beta_{3} D_{i t} \times R_{i t}+\varepsilon_{i t}$

$\mathbf{E P S}_{i t}$ is earning per share; $\mathbf{P}_{\mathbf{i t}}-\mathbf{1}$ is the closing prices of the firm at the end of year t-1; $\mathbf{R}_{\mathbf{i t}}$ is the market-adjusted stock return of the sample firm $i$ and year $\mathbf{t} ; \mathbf{D}_{\mathbf{i t}}$ is the dummy variable by donating 1 if $\mathbf{R}_{\mathbf{i t}}<0$ otherwise 0 if $\mathbf{R}_{\mathbf{i t}}>0$ by estimating G-Score in place of $\boldsymbol{\beta}_{\mathbf{2}}$ and C-Score in place of $\boldsymbol{\beta}_{3}$ according to the Basu (1997) model. 


$$
\begin{aligned}
& \frac{\text { EPS }_{\text {it }}}{\mathbf{P}_{\text {it }}-1}=\boldsymbol{\beta}_{\mathbf{0}}+\boldsymbol{\beta}_{\mathbf{1}} \mathbf{D}_{\mathrm{it}}+\mathbf{R}_{\mathrm{it}}\left(\mu_{\mathbf{0}}+\mu_{\mathbf{1}} \text { SIZE }_{\text {it }}+\mu_{\mathbf{2}} \mathbf{M T B}_{\mathrm{it}}+\mu_{\mathbf{3}} \mathbf{L E V}_{\mathrm{it}}\right)+ \\
& D_{i t} \times R_{i t}\left(\lambda_{0}+\lambda_{1} \text { SIZE }_{i t}+\lambda_{2} \text { MTB }_{i t}+\lambda_{3} L_{E V}\right)+\varepsilon_{i t}
\end{aligned}
$$

While the above equation is regressed by the annual cross-section and by putting obtained coefficients in $\boldsymbol{\lambda}_{\mathbf{0}} \boldsymbol{\lambda}_{\mathbf{1}} \boldsymbol{\lambda}_{\mathbf{2}} \boldsymbol{\lambda}_{\mathbf{3}}$ in equation (2) to obtain an annual index of accounting conservatism.

\section{Estimation of Stock Price Crash Risk}

According to (Xu et al., 2012) the ups and downs volatility ratio (DUVOL) is the proxy variable to measure the risk of the stock price crash. The calculation process is as follows: Firstly, we must remove the effect of market influences on specific stock returns and calculate the specific return (Wit) of stock $\mathrm{i}$ in the $\mathrm{t}$ week, as $\mathrm{Wit}=\ln \left(1+\boldsymbol{\varepsilon}_{\mathrm{it}}\right)$, that is the residual term of the model. The related values of stock price crash risk are measured according to the specific weekly return rate according to equation (5).

$\mathbf{R}_{\mathrm{it}}=\alpha_{0}+\beta_{1} \mathbf{R}_{\mathrm{mt}-2}+\beta_{2} \mathbf{R}_{\mathrm{mt}-1}+\beta_{3} \mathbf{R}_{\mathrm{mt}}+\beta_{4} \mathbf{R}_{\mathrm{mt}+1}+\beta_{5} \mathbf{R}_{\mathrm{mt}+2}+\varepsilon_{\mathrm{it}}$

While $\mathbf{R}_{\mathbf{i t}}$ is the return rate of stock $\mathrm{i}$ in the $\mathrm{t}$ week without cash dividend, and $\mathbf{R}_{\mathbf{m t}}$ is the return rate of market index points in the $\mathrm{t}$ week of the market. $\mathbf{R}_{\mathbf{m t}-\mathbf{2}} \& \mathbf{R}_{\mathbf{m t}-\mathbf{1}}$ are the $2^{\text {nd }}$ and $1^{\text {st }}$ lag series of the $\mathbf{R}_{\mathbf{m t}}$ while $\mathbf{R}_{\mathbf{m t + 1}} \& \mathbf{R}_{\mathbf{m t + 2}}$ are the $1^{\text {st }}$ and $2^{\text {nd }}$ lead series of the $\mathbf{R}_{\mathbf{m t}}$. Then, according to Wit, we construct an index to measure crash risk. The estimation process is as follows: First, all the weeks of the company $i$ in a certain year $t$ are divided into two categories. When the weekly-specific yield Wit is lower than the average of the weekly-specific yield Wi in that year, which is recorded as (Down-Week) $\mathbf{n}_{\text {down }}$. But when the week-specific rate of return Wit of the company $i$ is higher than the average rate of return Wi in that year, which is recorded as (Up-Week) $\mathbf{n}_{\mathbf{u p}}$. The calculation formula is as follows: Simply, the standard deviation of down-week is divided by the standard deviation of up-week. Then DUVOL is measured by taking the log of obtained answers according to the below-mentioned equation (6).

DUVOL $=\log \left\{\left[\left(\mathbf{n}_{\mathbf{u p}}-1\right) \sum_{\mathbf{d o w n}} \mathbf{W}_{\mathbf{i}, \mathbf{t}}^{\mathbf{2}}\right] /\left[\left(\mathbf{n}_{\mathbf{d o w n}}-1\right) \sum_{\mathbf{u p}} \mathbf{W}_{\mathbf{i}, \mathbf{t}}^{\mathbf{2}}\right]\right\}$

\section{Estimation of Managerial Ownership and Institutional Ownership}

This study considers managerial ownership structure as an attribute of the corporate governance mechanism that can be measured in two ways. The first one is managerial ownership that can be measured by obtaining the ratio of shares held by firm management and total shares of the firms. The second one is institutional ownership that can also be measured by obtaining the ratio of shares held by the different institutions' owners and total shares of the firm (Hajawiyah et al., 2020).

\section{Estimation of Control Variables}

This study considers the firm's profitability and firm's leverage as control variables. First, the firm's profitability ratio is measured as return on asset (ROA). Second, leverage (LEV) is measured by dividing the debt by to equity of the firm (Saeed \& Saeed, 2018).

\section{Regression Models}

To test the developed hypothesis, the following regression models as $\mathrm{A}, \mathrm{B}$, and $\mathrm{C}$ in Eq7, Eq8, and Eq9 accordingly have been developed in this study.

$$
\operatorname{Model}(\mathrm{A}): \mathbf{S P C R}_{\mathbf{i t}}=\boldsymbol{\beta}_{\mathbf{0}}+\boldsymbol{\beta}_{\mathbf{1}} \mathbf{A C C} \mathbf{i t}+\boldsymbol{\beta}_{\mathbf{2}} \mathbf{R O A} \mathbf{A}_{\mathrm{it}}+\boldsymbol{\beta}_{\mathbf{3}} \mathbf{L E V}_{\mathrm{it}}+\boldsymbol{\varepsilon}_{\mathrm{it}}
$$




$$
\begin{aligned}
& \operatorname{Model}(B): \text { SPCR }_{i t}=\boldsymbol{\beta}_{\mathbf{0}}+\boldsymbol{\beta}_{1} \mathbf{A C C}_{\mathrm{it}}+\boldsymbol{\beta}_{\mathbf{2}} \mathbf{M O}_{\mathrm{it}}+\boldsymbol{\beta}_{\mathbf{3}} \mathbf{A C C}_{\mathrm{it}} * \mathbf{M O}_{\mathrm{it}}+\boldsymbol{\beta}_{\mathbf{4}} \mathbf{R O A}_{\mathrm{it}}+ \\
& \beta_{5} \mathbf{L E V}_{\mathrm{it}}+\varepsilon_{\mathrm{it}} \\
& \operatorname{Model}(C): \mathbf{S P C R}_{\mathrm{it}}=\boldsymbol{\beta}_{\mathbf{0}}+\boldsymbol{\beta}_{\mathbf{1}} \mathbf{A C C}_{\mathrm{it}}+\boldsymbol{\beta}_{\mathbf{2}} \mathbf{I O}_{\mathrm{it}}+\boldsymbol{\beta}_{\mathbf{3}} \mathbf{A C C}_{\mathbf{i t}} * \mathbf{I O}_{\mathrm{it}}+\boldsymbol{\beta}_{\mathbf{4}} \mathbf{R O A}_{\mathrm{it}}+ \\
& \beta_{5} \mathbf{L E V}_{\text {it }}+\varepsilon_{\text {it }}
\end{aligned}
$$

\section{Multicollinearity Test}

This study makes sure that sample data is independent. The observations of sample variables are not correlated with each other. For this Variance Inflation Factor (VIF) and Tolerance tests are performed to detect the issue of multicollinearity among sample variables of this study. The VIF should be less than a score of 10 . The tolerance value should be less than 1 . This is the benchmark set by the researchers (Hajawiyah et al., 2020).

Table 1: Variance Inflation Factor (VIF) and Tolerance Test:

\begin{tabular}{||l||l||l|l||l||}
\hline Variable & $\begin{array}{l}\text { Coefficient } \\
\text { Variance }\end{array}$ & $\begin{array}{l}\text { Uncentered } \\
\text { VIF }\end{array}$ & $\begin{array}{l}\text { Centered } \\
\text { VIF }\end{array}$ & $\begin{array}{l}\text { Tolerance } \\
\text { 1/VIF }\end{array}$ \\
\hline \hline ACC & $7.04 \mathrm{E}-06$ & 1.3053 & 1.0951 & 0.9131 \\
\hline MO & $3.28 \mathrm{E}-06$ & 1.0128 & 1.0012 & 0.9988 \\
\hline \hline IO & $3.80 \mathrm{E}-06$ & 1.0654 & 1.0042 & 0.9958 \\
\hline ROA & 0.001917 & 1.2525 & 1.0227 & 0.9778 \\
\hline \hline LEV & $6.97 \mathrm{E}-07$ & 1.1069 & 1.1069 & 0.9034 \\
\hline
\end{tabular}

Table 1 presents the result of the VIF test. As we can see that the VIF score is less than 10. There is no issue of multicollinearity among the sample variables of this study. Furthermore, for this study, the tolerance score of each variable is obtained as one divided by the value of centered VIF that is less than 1 which shows also that multicollinearity does not exist among sample variables of this study.

\section{Selection of an Appropriate Model}

For the selection of an appropriate model for panel data analysis from the Fixed Effect Model and Random Effect Model. This study performs the Hausman test, F test, and LR test methods. These methods are recommended for the selection of an appropriate model based on these null and alternate hypotheses (Wang et al., 2020).

H0: Random effect model is appropriate for panel data analysis.

H1: Fixed effect model is appropriate for panel data analysis.

Table 2: Redundant Fixed Effect (F \& LR) Test:

\begin{tabular}{|l||l||l||l||}
\hline Effect Test & Statistic & d.f. & Prob. \\
\hline \hline Cross-Section F & 1.635223 & $(154,1855)$ & 0.0000 \\
\hline \hline Cross-Section Chi-Square & 256.503630 & 154 & 0.0000 \\
\hline
\end{tabular}

Table 2 probability values of the F test and LR test are 0.0000 and 0.0000 respectively, which are less than the significant level of 0.01. Hausman's test value is also observed during the regression analysis at less than 0.01. From the test results, we can accept the H1 that means Fixed Effect Model is an appropriate model for panel data analysis for this study. 


\section{Empirical Results}

\section{Descriptive Statistics}

Table 3 indicates the total number of observations $(\mathrm{N})$, mean, and median value of the sample variables of this study. The table of descriptive statistics shows the minimum and maximum values of the sample data of this study. This table also states the standard deviation (S.D.) along with the probability $(\mathrm{P})$ value of the data set that describes the sample variables at their significant level.

Table 3: Descriptive Statistics:

\begin{tabular}{|l||l||l||l|l|l||l|l||}
\hline Variable & Mean & Median & Minimum & Maximum & S.D. & N & P \\
\hline \hline SPCR & 0.0344 & 0.0114 & -0.6332 & 1.2580 & 0.2010 & 2015 & 0.0000 \\
\hline \hline ACC & 0.7730 & 0.4679 & -4.2490 & 6.5474 & 6.3313 & 2015 & 0.0000 \\
\hline \hline MO & 0.0266 & 0.0625 & 0.0000 & 0.8682 & 0.4710 & 2015 & 0.0000 \\
\hline \hline IO & 0.0567 & 0.5410 & 0.0000 & 0.8331 & 0.3021 & 2015 & 0.0000 \\
\hline \hline ROA & 0.0489 & 0.0425 & -0.6308 & 0.6696 & 0.1034 & 2015 & 0.0000 \\
\hline \hline LEV & 0.0065 & 0.0218 & 0.0000 & 1.4064 & 0.1368 & 2015 & 0.0000 \\
\hline \hline
\end{tabular}

\section{Correlation Analysis}

Table 4 presents the result of the correlation matrix. By correlation matrix, researchers try to analyze "a phenomenon in which two or more independent variables are correlated with each other in multiple regression and if reported values are less than 0.5 thus, no multicollinearity exists among independent variables" (Latif et al., 2020).

Table 4: Correlation Analysis:

\begin{tabular}{|l||l||l||l||l||l|l||}
\hline Variable & SPCR & ACC & MO & IO & ROA & LEV \\
\hline \hline SPCR & 1.0000 & $\ldots$ & $\ldots$ & $\ldots$ & $\ldots$ & $\ldots$ \\
\hline \hline ACC & -0.0105 & 1.0000 & $\ldots$ & $\ldots$ & $\ldots$ & $\ldots$ \\
\hline MO & 0.0132 & -0.0116 & 1.0000 & $\ldots$ & $\ldots$ & $\ldots$ \\
\hline \hline IO & -0.0332 & 0.0042 & -0.0086 & 1.0000 & $\ldots$ & $\ldots$. \\
\hline ROA & 0.0066 & 0.0062 & -0.0183 & 0.0573 & 1.0000 & $\ldots$ \\
\hline \hline LEV & -0.0041 & -0.0631 & 0.0035 & 0.0062 & 0.0314 & 1.0000 \\
\hline \hline
\end{tabular}

The correlation matrix indicates a value of -0.0105 which shows there is a negative correlation between SPCR and ACC that supports to $\mathrm{H} 1$ of this study. There is a positive correlation between SPCR and MO but there is a negative correlation between ACC and MO as per reported figures by +0.0132 and -0.0116 respectively because these values indicate the strength of the complementary role of $\mathrm{MO}$ as per its influence according to $\mathrm{H} 2$ of this study. But a negative correlation has been found for SPCR and IO with a value of -0.0332 and on the other hand, there is a positive correlation between ACC and IO (0.0042) that also shows the moderating influence of ACC and IO on SPCR in support of H3 of this study.

Further, Table 4 shows that there is a positive correlation of ROA with SPCR (0.0066), ACC (0.0062), and IO (0.0573), but its negative strength has been reported with MO by -0.0183 respectively. At the end of correlation analysis, the correlation strength of LEV has been analyzed as $2^{\text {nd }}$ control variable of this study which indicates its negative correlation with SPCR and ACC because its reported figures are -0.0041 and -0.0631 accordingly. While values of MO (0.0035), IO (0.0062), and ROA (0.0314) state that there is a positive strength of LEV by respective correlation with them. 


\section{Regression Results}

To test hypothesis 1 (H1), this study examines the effect of accounting conservatism (ACC) on a firm's stock price crash risk (SPCR) by adding return on asset (ROA) and debt to equity ratio (LEV) as control variables to model (A) by regression analysis of equation (7).

Table 6: Result of Fixed Effect Model (A) by Regression Equation (7):

\begin{tabular}{||l||l||l|l||l||}
\hline Variable & Coefficient & Std. Error & t-Statistics & Prob. \\
\hline C & 0.0640 & 0.0084 & 7.5390 & $0.0000^{* * * *}$ \\
\hline \hline ACC & -0.0333 & 0.0086 & -3.8738 & $0.0001^{* * *}$ \\
\hline \hline ROA & -0.0176 & 0.0632 & -1.2043 & 0.2286 \\
\hline \hline LEV & -0.0100 & 0.0025 & -3.9149 & $0.0001^{* * *}$ \\
\hline \hline F-Statistic & 1.6515 & $\ldots$ & $\ldots$. & $0.0000^{* * *}$ \\
\hline \hline Adj. R-Sq & 0.4831 & $\ldots$. & $\ldots$. & $\ldots$. \\
\hline
\end{tabular}

(Dependent Variable: SPCR), ***,**, *, Statically Significant at $0.01,0.05,0.1$ respectively.

Table 6 shows the results of the fixed effect model with the help of the Hausman test. The Fstatistics is also significant that indicates that the model is fit. As per this table, the coefficient between ACC and SPCR is -0.0333 which is significantly negatively correlated with probability (P-value) of 0.0001 at less than 0.01. This significant negative correlation between shows that sample firms of Pakistan are choosing effective accounting policies such as the conservatism principle of accounting to control the firm's stock price crash risk. This shows that H1 of this study is true according to the research study of (Lafond \& Watts, 2008).

Furthermore, as per Table 6 coefficient value of ROA is negative (-0.0176) but not significant because its P-value is greater than 0.05 . The correlation coefficient between LEV and SPCR is 0.0100 at a significant negative relationship because its P-value $(0.0001)$ is less than 0.01 . This indicates that the firm's debt to equity ratio is favorable regarding SPCR.

To test hypothesis $2(\mathrm{H} 2)$, this study examines the moderating effect of managerial ownership (MO) on the significant negative effect of accounting conservatism (ACC) on a firm's stock price crash risk (SPCR) by adding return on asset (ROA) and debt to equity ratio (LEV) as control variables to model (B) by regression analysis of equation (8).

Table 7 shows the results of the fixed effect model with the help of the Hausman test. The value of F-statistics is significant that indicates that this model is fit. As per the results of this table, there is a significant negative correlation between ACC and SPCR with -0.0398 as coefficient value and 0.0000 as P-value at less than 0.01 .

Table 7: Result of Fixed Effect Model (B) by Regression Equation (8):

\begin{tabular}{|l||l||l|l||l||}
\hline Variable & Coefficient & Std. Error & t-Statistics & Prob. \\
\hline \hline C & 0.0745 & 0.0099 & 7.4721 & $0.0000^{* * *}$ \\
\hline \hline ACC & -0.0398 & 0.0091 & -4.3593 & $0.0000^{* * *}$ \\
\hline \hline MO & -0.0233 & 0.0120 & -1.9272 & $0.0541^{*}$ \\
\hline \hline ACC*MO & 0.0304 & 0.0147 & 2.0577 & $0.0398^{* *}$ \\
\hline ROA & -0.0773 & 0.0631 & -1.2236 & 0.2212 \\
\hline \hline LEV & 0.0120 & 0.0027 & -4.3953 & $0.0000^{* * *}$ \\
\hline \hline F-Statistic & 1.6628 & $\ldots$. & $\ldots$. & $0.0000^{* * *}$ \\
\hline \hline Adj. R-Sq & 0.4973 & $\ldots$. & $\ldots$ & $\ldots$. \\
\hline
\end{tabular}

(Dependent Variable: SPCR), ***, **, *, Statically Significant at $0.01,0.05,0.1$ respectively. 
Furthermore, Table 7 shows the moderating effect of managerial ownership (ACC*MO) on the significant negative relationship between ACC and SPCR is positively significant because the coefficient value of $\mathrm{ACC}^{*} \mathrm{MO}$ is 0.0304 and its $\mathrm{P}$-value is 0.0398 which is less than 0.05 . This indicates that a firm's managerial ownership applies the principle of accounting conservatism to anticipate bad news than good news for their benefit. This also shows that the firm's management in Pakistan tries to hide the bad news that enhances the firms' stock price crash. This confirms that $\mathrm{H} 2$ of this study is true according to the research study of (Jin \& Myers, 2006) and (An \& Zang, 2013).

To test hypothesis 3 (H3), this study examines the moderating effect of institutional ownership (IO) on the significant negative effect of accounting conservatism (ACC) on a firm's stock price crash risk (SPCR) by adding return on asset (ROA) and debt to equity ratio (LEV) as control variables to model (C) by regression analysis of equation (9).

Table 8 shows the results of the fixed effect model with the help of the Hausman test. F-statistics is also significant that shows this model is fit. As per the results of this table, there is a significant negative correlation between ACC and SPCR with -0.0350 as coefficient value and 0.0001 as Pvalue at less than 0.01 .

Table 8: Result of Fixed Effect Model (C) by Regression Equation (9):

\begin{tabular}{||l||l||l||l||l||}
\hline \hline Variable & Coefficient & Std. Error & t-Statistics & Prob. \\
\hline \hline $\mathrm{C}$ & 0.0664 & 0.0089 & 7.4539 & $0.0000 * * *$ \\
\hline \hline ACC & -0.0350 & 0.0091 & -3.8143 & $0.0001 * * *$ \\
\hline \hline IO & -0.0045 & 0.0054 & -0.8356 & 0.4034 \\
\hline \hline ACC $*$ IO & 0.0028 & 0.0058 & 0.4783 & 0.6324 \\
\hline \hline ROA & -0.0745 & 0.0632 & -1.1790 & 0.2385 \\
\hline \hline LEV & 0.0105 & 0.0027 & -3.8650 & $0.0001 * * *$ \\
\hline \hline F-Statistic & 1.6387 & $\ldots .$. & $\ldots$. & $0.0000 * * *$ \\
\hline \hline Adj. R-Sq & 0.4805 & $\ldots$. & $\ldots$. & $\ldots$. \\
\hline
\end{tabular}

(Dependent Variable: SPCR), ***, **, *, Statically Significant at 0.01, 0.05, 0.1 respectively.

Furthermore, Table 8 shows the moderating effect of managerial ownership (ACC*IO) on the significant negative relationship between ACC and SPCR is positively insignificant because the coefficient value of ACC*IO is 0.0028 and its $\mathrm{P}$-value is 0.6324 which is greater than 0.05 . This indicates that the firm's institutional ownership does not have access to the information. This is because of the weak governance system of Pakistan. This also shows that the ownership structure is centralized in Pakistan. This is confirmation of the wrongness of $\mathrm{H} 3$ of this study according to the point of view of (Wang et al., 2020). The management of the firm applies conservatism to anticipate bad news for their benefits because of agency conflict among the firms' investors and managers according to agency theory (Stein, 2003).

\section{Discussion}

This study shows that there is a significant negative effect of accounting conservatism on the stock price crash risk of the firm. This states that the application of accounting conservatism by the firm management is helpful to control the risk associated with stock prices. This also indicates that firm management chooses the best accounting measures to minimize the risk of stock prices by identification of crash news (bad news). This indication is in line with positive accounting theory (PAT). PAT tries to explain the actions of the firm management. PAT is applied for the selection of accounting measures (Watts \& Zimmerman, 1986). 
The positive accounting theory is correlated with the conservatism principle of accounting. PAT also discusses the reasons, why the firm's management adopt this principle? The research conducted by (Wang et al., 2020) and (Lafond \& Watts, 2008) answer this question. The acceptance of the first assumption of this study also supports their answer. The result of this study is according to the results of their studies that indicate that conservatism reduces the stock price crash risk of the firm.

This study shows the significant negative effect of managerial ownership on the reduction of stock price crash risk of the firm. This indicates that the firm's management considers its interest rather than the interest of the investors of stocks. This is because of a conflict of interest. This result is in the line of agency theory (Jensen \& Meckling, 1976). The agency conflict comes into consideration when management thinks about the maximization of the firm's profit for selfinterest.

Further, the study shows the significant positive moderating effect of managerial ownership with an application of conservatism on the stock price crash risk of the firm. This result is in the line of positive accounting theory and agency theory. The firm's management chooses the conservatism principle as an accounting measure for the indication of bad news for the selfinterest and inside trading of stocks. The firm's managers hide bad information that controls the collapse risk for temporary but when this information comes into the stock market then prices of stock collapse and risk associated with stock prices increase. The result of this study is according to the arguments of (Jin \& Myers, 2006) and (An \& Zang, 2013). The second assumption of this study has been accepted in support of their research's results that state that managerial ownership increases the crash risk with the application of conservatism to hide the bad news for self-interest rather than to protect the interest of the investors (Lafond \& Watts, 2008) and (Lafond \& Roychowdhury, 2008).

This shows that there is an insignificant negative effect of institutional ownership on stock price crash risk. This result is not in the line of agency theory. This is because of the interest of institutional investors. The institutional investors do not support the conflicting interest and inside trading of stock by the management for self-interest. This result is in the line of resource dependency theory (RDT). The firm's management needs useful resources to run the operations of the firm. These resources are held by different institutions. Every institutions and resource provider have an interest. They demand proper accounting records and purpose guidelines in the decision-making process. They keep eye on the actions of the firms' managers (Pfeffer \& Salanic, 1978).

Further, this study shows an insignificant positive moderating effect of institutional ownership with the adoption of the conservatism principle of accounting on the stock price crash risk. This result is in the line of positive accounting theory because a firm's management chooses conservatism as an accounting measure (Watts \& Zimmerman, 1990) and (Watts \& Zimmerman, 2003). This result supports the theory of resource dependency theory but does not according to the agency theory because resource providers have a keen interest in the performance of the managers. They need every type of information (good and bad news). They suggest applying conservatism for the identification of good and bad signals about the stock prices and their crash with associated risk. Thus, managers do not have a chance to hide the bad news for self-interest (Pfeffer and Salanic, 1978) and (Stein, 2003). The third assumption of this study has been rejected based on such issues and theoretical arguments. 


\section{Conclusion}

This study investigates the answers to questions related to the effect of accounting conservatism on a firm's stock price crash risk with the moderating role of managerial ownership and institutional ownership in the context of Pakistan for 155 nonfinancial firms listed in the Pakistan Stock Exchange (PSX). This study applies the VIF test to indicate the issue of multicollinearity and the Hausman test for appropriate model selection for regression analysis of 2015 observations for 13 years (2007-2019).

This study finds that accounting conservatism reduces the stock price crash risk which is a favorable aspect of the principle of accounting conservatism to control risk factors at a possible level for the firms' management as well as investors of the firms. This study also finds that managerial ownership with accounting conservatism enhances the stock price crash risk which is unfavorable for both the management and investors of the firms. But management tries to escape from such issues with the help of conservatism by hiding bad news for personal benefits. Further, this study finds that there is no influence of institutional owners on the stock price crash risk of the firm in the association of conservatism. This is because of the weak governance system of Pakistan while as we know that the ownership structure is centralized in Pakistan. There is a conflict of interest among managers and investors. There is an element of Horse-Trading, agency conflicts, and corrupt practices by brokers, investors, and managers. This is all about weak rule of law because no proper enforcement of rules and regulations in Pakistan to control such issues. After all, the results of this study have been summarized in Table 9.

The findings of this study are in the line of agency theory that indicates that a weak governance system does not demand a high level of conservatism for bad news anticipation to control the stock price crash risk. The regulatory bodies of developing countries with the support of policymakers should construct an effective accounting system according to the results of this study that provides equal information to all regardless of the bad news and the good news.

Table 9: Hypotheses Testing Summary:

\begin{tabular}{|c|c|c|c|c|c|}
\hline Hypothesis & Coefficient & Std. Error & $\mathrm{t}$-Statistics & Prob. & Result \\
\hline $\mathrm{H} 1$ & -0.0333 & 0.0086 & -3.8738 & $0.0001 * * *$ & ACCEPTED \\
\hline $\mathrm{H} 2$ & 0.0304 & 0.0147 & 2.0577 & $0.0398 * *$ & ACCEPTED \\
\hline $\mathrm{H} 3$ & 0.0028 & 0.0058 & 0.4783 & 0.6324 & REJECTED \\
\hline
\end{tabular}

This study is limited to the developing economy. This study is limited to Pakistan. This study is limited to the nonfinancial sector. This study is limited to sample size. This study is limited to attributes of the good corporate governance system. This study is limited to measures of conservatism and stock price crash risk.

For future research, this study can be replicated with the introduction of a developed economy like the USA or China, etc. This study can be replicated with an introduction of another developing country like India or Bangladesh etc. This study may also be conducted with the addition of other attributes of the corporate governance mechanism like board size or audit committee independence, etc. This study can be enhanced to measure the accounting conservatism other than C-score. This study may be conducted by measuring a firm's stock price crash risk other than DUVOL. 


\section{References}

Ahmed, A. S., \& Duellman, S. (2007). Accounting conservatism and board of director characteristics: An empirical analysis. Journal of Accounting and Economics, 43(2-3), 411-437.

Alhayati, F. (2013). Pengaruh Tingkat Hutang (Leverage) dan Tingkat Kesulitan Keuangan

An, H., \& Zhang, T. (2013). Stock price synchronicity, crash risk, and institutional investors. Journal of Corporate Finance, 21(1), 1-15.

Basu, S. (1997). The conservatism principle and the asymmetric timeliness of earnings1. Journal of accounting and economics, 24(1), 3-37.

Beekes, W., Pope, P., \& Young, S. (2004). The link between earnings timeliness, earnings conservatism, and board composition: Evidence from the U.K. Corporate Governance, 12(1), 47-59.

Chen, P., \& Zhou, J. (2016). Effects of the built environment on automobile-involved pedestrian crash frequency and risk. Journal of Transport \& Health, 3(4), 448-456.

Ding, Y., Zhang, H., and Zhang, J. (2007). Private vs State ownership and earnings management: Evidence from Chinese listed companies. Corporate Governance: An International Review, 15(2), 223-238.

Hajawiyah, A., Wahyudin, A., \& Pahala, I. (2020). The effect of good corporate governance mechanisms on accounting conservatism with leverage as a moderating variable. Cogent Business \& Management, 7(1), 1779479.

Hu, J., Li, A. Y., \& Zhang, F. (2014). Does accounting conservatism improve the corporate information environment? Journal of International Accounting Auditing \& Taxation, 23(1), 32-43.

Hunjra, A. I., Mehmood, R., \& Tayachi, T. (2020). How Do Corporate Social Responsibility and Corporate Governance Affect Stock Price Crash Risk? Journal of Risk and Financial Management, 13(2), 30.

Hutton, A. P., Marcus, A. J., \& Tehranian, H. (2009). Opaque financial reports, R2, and crash risk. Journal of Financial Economics, 94(1), 67-86.

Jensen, M. C., \& Meckling, W. H. (1976). Theory of the firm: Managerial behavior, agency costs, and ownership structure. Journal of financial economics, 3(4), 305-360.

Jin, L., \& Myers, S. C. (2006). R2 around the world: new theory and new tests. Journal of Financial Economics, 79(2), 257-292.

Khan, M., \& Watts, R. L. (2009). Estimation and empirical properties of a firm-year measure of accounting conservatism. Journal of Accounting and Economics, 48(2-3), 132-150.

Kim, B. and Jung, K. (2007). The influence of tax costs on accounting conservatism. KAIST, Business School Working Paper Series Index.

Kim, J. B., Li, Y., \& Zhang, L. (2011). CFOs versus CEOs: Equity incentives and crashes. Journal of Financial Economics, 101(3), 713-730.

Kim, J., \& Zhang, L. (2016). Accounting conservatism and stock price crash risk: Firm-level evidence. Contemporary Accounting Research, 33(1), 412-441.

Kung, F., Cheng, L., and James, K. (2010). Effects of corporate ownership structure on earnings conservatism. Asian Journal of Finance \& Accounting, 2(1), 46-67.

LaFond, R., \& Roychowdhury, S. (2008). Managerial ownership and accounting conservatism. Journal of Accounting Research, 16(1), 101-135.

Lafond, R., \& Watts, R. L. (2008). The information role of conservatism. The Accounting Review, 83(2), 447-478.

Lara, J. M. G., Osma, B. G., \& Penalva, F. (2009). Accounting conservatism and corporate governance. Review of accounting studies, 14(1), 161-201.

Latif, Khalid, Ghulam Mujtaba Chaudhary, \& Aon Waqas. (2020). Relationship Between Accounting Conservatism and Investment Efficiency with the Moderating Role of IFRS Adoption in Pakistan. Journal of Accounting and Finance in Emerging Economies 6(4) 
1139-1150.

Lemons, M., \& Lins, K. (2003). Ownership Structure. Corporate Governance, and Firm Value. William Davidson Working Paper, 393.

Lin, F., Wu, C. M., Fang, T. Y., \& Wun, J. C. (2014). The relations among accounting conservatism, institutional investors, and earnings manipulation. Economic Modelling, 37(1), 164-174.

Mitton, T. (2002). A cross-firm analysis of the impact of corporate governance on the East Asian financial crisis. Journal of financial economics, 64(2), 215-241.

Mohammed, N. F., Ahmed, K., \& Ji, X. D. (2010). Accounting conservatism, corporate governance, and political influence: evidence from Malaysia (Working Paper). LaTrobe University (SSRN: 1716485).

Mohammed, N., Ahmed, K., and Ji, X. (2017). Accounting conservatism, corporate governance, and political connections. Asian Review of Accounting, 25(2), 288-318.

Perusahaan terhadap Konservatisme Akuntansi. Jurnal Akuntansi, 1(1), 1-23.

Pfefer, J., \& Salancik, G. (1978). The external control of organizations.

Quan, X., \& Xiao, H. (2016). The impact of social responsibility disclosure on stock market crash risk: A mediating mechanism based on accounting conservatism. China Soft Science, (6), 80-97.

Ruch, G. W., \& Taylor, G. (2015). Accounting conservatism: A review of the literature. Journal of Accounting Literature, 34, 17-38.

Saeed, M.B., \& Saeed, S.K. (2018) Corporate Governance and Accounting Conservatism: Moderating role of Disclosure Quality and Audit Quality. Business and Economic Review, 10(2). 123-150.

Stein, J. C. (2003). Agency, information, and corporate investment. Handbook of the Economics of Finance, 1, 111-165.

Verdi, R. S. (2006). Financial reporting quality and investment efficiency. Available at SSRN 930922.

Wang, C., \& Xie, Y. (2013). Accounting conservatism, information opacity, and stock price risk. Management Science, 26(1), 68-79.

Wang, L. (2015). Accounting conservatism, product market competition, and stock price crash risk. Journal of Nanjing Audit Institute, (6), 35-44.

Wang, Q., Li, X., \& Liu, Q. (2020). Empirical research of accounting conservatism, corporate governance, and stock price collapse risk based on a panel data model. Connection Science, 1-16.

Watts, R. L. (2003). Conservatism in accounting part I: explanations and implications. Accounting Horizons, 17(3), 207-221.

Watts, R. L., \& Zimmerman, J. L. (1986). Positive accounting theory.

Watts, R. L., \& Zimmerman, J. L. (1990). Positive accounting theory: a ten-year perspective. Accounting Review, 131-156.

Watts, R. L., \& Zimmerman, J. L. (2003). Positive accounting theory: a ten-year perspective. Accounting Review, 131-156.

Xu, N., Jiang, X., Chan, K. C., \& Yi, Z. (2013). Analyst coverage, optimism, and stock price crash risk: Evidence from China. Pacific-Basin Finance Journal, 25, 217-239.

Xu, N., Jiang, X., Yi, Z., \& Xu, X. (2012). Analysis's conflict of interest, optimism bias, and stock price crash risk. Economic Research, 47(7), 127-140.

Yang, K., Wang, X., \& Yu, R. (2018). A Bayesian dynamic updating approach for urban expressway real-time crash risk evaluation. Transportation research part $C$ : emerging technologies, 96, 192-207.

Young, M. N., Peng, M. W., Ahlstrom, D., Bruton, G. D., and Jiang, Y. (2008). Corporate governance in emerging economies: A review of the principal perspective. Journal of management studies, 45(1), 196-220.

Zheng, B., \& Liu, Y. (2014). Applicability of C-score in China. Forecast, 33(2), 71-74. 